\title{
Analisis Perencanaan Jarak Celah Udara Pada Generator Axial
}

\author{
Syafriyudin ${ }^{1}$, M. Suyanto ${ }^{2}$ \\ Jurusan Teknik Elektro Institut Sains dan Teknologi AKPRIND Yogyakarta

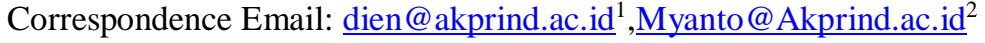

\begin{abstract}
Abstrak. Generator menggunakan magnet permanen sehingga tidak memerlukan eksitasi awal dalam menghasilkan tegangan. Desain generator adalah tipe fluks aksial, menggunakan magnet permanen tipe keramik (NdFeB), menggunakan dua rotor stator mengapit. Untuk penggunaan listrik, tegangan AC berubah menjadi tegangan DC menggunakan penyearah untuk pengisian akumulator. Celah udara pada generator axial merupakan jarak antara rotor dan stator. Celah udara juga menjadi tempat perpindahan medan magnet melewati kumparan pada stator sehingga menghasilkan nilai fluks magnet yang mempengaruhi tegangan induksi pada kumparan. Semakin cepat rotasi, semakin besar tegangan yang dihasilkan. Generator axial ini yang telah dirancang dapat menghasilkan frekuensi $\pm 50 \mathrm{~Hz}$, tegangan efektif $\pm 22 \mathrm{~V}$ saat celah udara $2 \mathrm{~mm}$, pengukuran frekuensi memiliki kesalahan sebesar 10-20 Hz dan persentase kesalahan sebesar 5-10\%, dengan hasil pengukuran arus induksi yang memiliki besar tegangan yang sama.
\end{abstract}

Kata kunci: generator axial, celah udara, magnet permanen,

Abstract. The generator uses a permanent magnet so it does not require initial excitation to generate a voltage. The generator design is axial flux type, uses ceramic type permanent magnet ( $\mathrm{NdFeB})$, uses two flanking stator rotors. For electricity use, the AC voltage is changed to DC voltage using a rectifier for charging the accumulator. The air gap in the axial generator is the distance between the rotor and the stator. The air gap is also a place for the transfer of the magnetic field through the coil on the stator to produce a magnetic flux value that affects the induced voltage in the coil. The faster the rotation, the greater the voltage generated. This axial generator that has been designed can produce a frequency of $\pm 50 \mathrm{~Hz}$, an effective voltage of $\pm 22 \mathrm{~V}$ when the air gap is $2 \mathrm{~mm}$, the frequency measurement has an error of 10-20 Hz and an error percentage of 5-10\%, with the results of measuring the induced current that has a large the same voltage.

Keywords: axial generator, air gap, permanent magnet,

\section{PENDAHULUAN.}

Kebutuhan listrik Nasional terus meningkat setiap tahunnya dan tercatat masih banyak wilayah Indonesia yang belum teraliri listrik, terutama daerah terpencil, perbatasan dan pulau-pulau terluar [16] Peningkatan kebutuhan energi listrik akan berdampak pada peningkatan kebutuhan energi konvensioanal, persediaan energi konvensioanal yang ada akan berkurang dan tidak menutup kemungkinan akan terjadi kelangkaan. Pembangkit Listrik Tenaga Mikrohidro (PLTmH) merupakan salah satu solusi alternatif untuk menjawab permasalahan-permasalahan tersebut diatas. Mikrohidro adalah istilah yang digunakan untuk instalasi pembangkit listrik tenaga air berskala kecil ini, untuk menghasilkan energi listrik [18] turbin pada PLTMH memiliki kecepatan putar yang rendah Dengan demikian, dibutuhkan inovasi terhadap teknologi konversi energi utama sistem tersebut, yaitu komponen generator listrik magnet permanen tipe fluks radial dan aksial [19].

Generator komersial yang populer saat ini adalah jenis high speed induction, dimana sistem ini membutuhkan kecepatan putaran tinggi. Untuk menggerakkan generator biasanya membutuhkan sistem motor bakar yang menggunakan bahan bakar dari fosil (batubara, minyak bumi dan gas) untuk menghasilkan medan magnet induksi [7], telah membuktikan bahwa performa sistem energi turbin hidrokinetik dengan menggunakan generator magnet permanen fluks aksial pada putaran rendah $450 \mathrm{rpm}$ dapat menghasilkan energi listrik $1 \mathrm{~kW}$. Perbedaan desain generator tipe fluks radial dan aksial masing-masing ditunjukkan pada Gambar 1 [3.6]

Untuk memenuhi peningkatan kebutuhan akan energi listrik maka diperlukan juga pengembangan sistem pembangkit energi listrik alternatif yang dapat diperbaharui (renewable).Pengembangan dan penerapan sistem pembangkit energi listrik alternatif yang dapat diperbaharui (renewable) dengan memanfaatkan beberapa sumber energi seperti: air, angin dan surya serta untuk sistem pengisian baterai. Salah satunya diperoleh dengan melakukan konversi energi mekanik ke energi listrik melalui alat yang dikenal dengan nama generator sinkron.

Generator sinkron berdasarkan jenis magnetnya terbagi menjadi dua jenis yaitu generator magnet permanen dan generator non-magnet permanen.Perbedaan kedua jenis ini yaitu generator magnet permanen sifat kemagnetan tinggi dan tidak teroksidasi di udara sedangkan non magnet permanen sangat mudah teroksidasi di udara.Lalu, berdasarkan arah fluksi magnetik, generator magnet permanen terdiri dari dua jenis yaitu fluksi radial dan fluksi aksial.Generator tipe fluksi aksial memiliki keunggulan yaitu tidak bising, ukurannya kecil, perawatan dan konstruksi sederhana [2][4].Generator sinkron magnet permanen tipe aksial merupakan generator yang posisi rotor dan statornya tegak lurus terhadap 
porosnya.Generator ini menggunakan magnet permanen pada rotor, sedangkan stator dirancang menggunakan kawat tembaga terisolasi yang dibungkus dengan bahan komposit
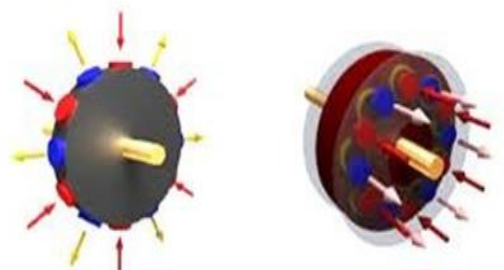

Gambar 1. Generator magnet permanen tipe (a) fluks radial dan (b) fluks aksial [3]

efek air gap terhadap performa generator listrik tipe fluks aksial berbasis magnet permanen $\mathrm{NdFeB}$ dimana peningkatan remanansi magnet berbanding lurus terhadap peningkatan output tegangan. Sebaliknya, peningkatan ukuran air gap menurunkan tegangan output secara linier. Hal ini disebabkan oleh adanya penurunan magnetik flux density secara exponensial [1]

Kelebihan dari generator fluks aksial antara lain dapat didesain sehingga memiliki kutub-kutub magnet yang lebih banyak sehingga sesuai untuk aplikasi generator kecepatan rendah [17]. Selain itu, generator aksial memiliki konstruksi yang lebih pendek, kompak, strukturnya kuat, dan tingkat efisiensi tinggi karena tidak timbul rugi-rugi daya pada kumparan rotor. Aplikasi generator magnet permanen tipe aksial sangat tepat untuk pembangkit listrik skala kecil, seperti menggunakan tenaga angin atau air [12].

Di lain pihak, terdapat potensi penyediaan energi listrik yang berasal dari pembangkit listrik dengan daya putar rendah, seperti mikrohidro, tenaga geraknya bersumber pada aliran air, angin atau gelombang laut [5]. Performa komponen generator pada tipe pembangkit listrik ini sangat tergantung pada jumlah dan distribusi medan magnetik dari magnet permanen yang digunakan. Selain itu pengaruh parameter desain, seperti air gap dan kecepatan putar juga mempengaruhi unjuk kerja generator tersebut [11].

Perencanaan generator sinkron magnet permanen satu fasa menggunakan magnet Neodynium Ferit Boron (NdFeB) tipe Neoflux-30 yang dioperasikan pada kecepatan $750 \mathrm{rpm}$. menghasilkan efisiensi sebesar 32,84 [14], Simulasi untuk mendapatkan rapat fluks pada kumparan stator menggunakan aplikasi FEMM 4.2. dikakukan dengan variasi lebar celah serta kedalaman dari tebal magnet. Rapat fluks yang didapatkan digunakan untuk memperkirakan output tegangan dan daya generator. [13]. Analisis elemen hingga kerapatan fluks magnet antara magnet permanen yang dipasang pada cakram rotor di mana ketebalan celah udara fiktif ditetapkan sebagai variabel untuk menentukan jarak maksimum.[9]

Penerapan perangkat lunak Elemen Hingga Analisis (FEA) digunakan untuk menghitung kerapatan fluks magnet permanen pada ukuran celah udara yang berbeda dengan menggunakan software (ANSOFT Maxwell) nya untuk mengetahui hubungan antara ukuran celah udara dan kinerja keluaran generator dengan mengubah ukuran celah udara [20]

Proses desain dan pembuatan generator magnet permanen fluks aksial untuk aplikasi elektrifikasi pedesaan dengan biaya mirah, di mana produksi lokal turbin angin kecil dipertimbangkan. Proses ini didasarkan pada desain sumber terbuka dan manual konstruksi yang sudah ada, Penekanan diberikan pada penggunaan alat dan teknik sederhana untuk mencapai biaya yang lebih rendah. [15]. Menggunakan metode Finite Elements dan computer aided design (CAD) lebih khusus lagi software comsol multiphysics untuk mendapatkan hasil pengoperasian generator yang baik, dan untuk struktur ini memecahkan masalah distribusi garis medan magnet pada kumparan jangkar dan induktor generator, mengamati pengaruh pada tegangan dari kecepatan linier [8]

Penelitian ini melakukan proses perancangan dan uji performa generator tipe aksial fluks satu fasa menggunakan magnet permanen $\mathrm{NdFeB}$, karena jenis Magnet permanen $\mathrm{NdFeB}$ merupakan magnet remanensi medan magnetik yang paling baik. Analisa unjuk kerja generator dilakukan dengan variasi air gap dan kecepatan putar rotor. Generator fluks aksial dirancang menggunakan satu buah stator dan dua buah rotor yang saling berpasangan. Pada bagian stator tersusun kumparan sebagai penghantar arus listrik, sedangkan pada bagian rotor masing-masing tersusun sebanyak 12 buah magnet permanen NdFeB .

\section{METODE}

\section{Prinsip Kerja Gnerator Fluks Aksial.}

Prinsip kerja dari generator fluks aksial sebenarnya tidak jauh berbeda dengan prinsip kerja generator konvensional yang memiliki fluks radial. Hanya saja pada generator fluks aksial memiliki medan megnet tetap yang berasal dari magnet permanen dirotornya sehingga tidak memerlukan pencatuan arus searah pada rotornya. Medan magnet dari rotor tersebut yang akan menembus bidang kumparan stator sehingga fluks pada stator. Besar nilai fluks akan berubah -ubah karena adanya perubahan $\theta$. Sudut $\theta$ berubah karena medan magnet yang bergerak menembus stator dan menghasilkan sudut tembus terhadap bidang normal stator yang berubah - ubah. Perubahan fluks terhadap waktu akan menghasilkan ggl induksi.

Gaya gerak listrik induksi (ggl) adalah timbulnya gaya gerak listrik di dalam kumparan yang mencakup sejumlah fluks garis gaya medan magnetik, bilamana banyaknya fluks garis gaya itu divariasi. Dengan kata lain, akan timbul gaya gerak listrik di dalam kumparan apabila kumparan itu berada di dalam medan magnetik yang kuat medannya berubah-ubah terhadap waktu.

Konsep gaya gerak listrik pertama kali dikemukakan oleh Michael Faraday, yang melakukan penelitian untuk 
menentukan faktor yang memengaruhi besarnya ggl yang diinduksi. Dia menemukan bahwa induksi sangat bergantung pada waktu, yaitu semakin cepat terjadinya perubahan medan magnetik, ggl yang diinduksi semakin besar, dapat dinyatakan bahwa jika fluks yang melalui loop kawat penghantar dengan $\mathrm{N}$ lilitan berubah sebesar $\Delta \Phi B$ dalam waktu $\Delta \mathrm{t}$.

Yang dikenal dengan Hukum Induksi Faraday, yang berbunyi:

"gaya gerak listrik (ggl) induksi yang timbul antara ujung-ujung suatu loop penghantar berbanding lurus dengan laju perubahan fluks magnetik yang dilingkupi oleh loop penghantar tersebut".

Tanda negatif pada persamaan diatas menunjukkan arah ggl induksi. Apabila perubahan fluks ( $\Delta \Phi$ ) terjadi dalam waktu singkat ( $\Delta \mathrm{t} \rightarrow 0$ ), maka ggl induksi menjadi:

$$
\varepsilon=-N \frac{d \Phi_{B}}{d t}
$$

Dengan:

$\varepsilon \quad=$ ggl induksi (volt)

$\mathrm{N}$ = banyaknya lilitan kumparan

$\Delta \Phi B=$ perubahan fluks magnetik (weber)

$\Delta \mathrm{t}=$ selang waktu (s)

\section{Rancangan Rotor dan Celah Udara}

Perencanaan generator fluks aksial yang dapat menghasilkan tegangan generator 100 volt, dengan kecepatan putaran $200 \mathrm{Rpm}$ pada frekuensi $50 \mathrm{~Hz}$ tegangan out put akan naik sesuai dengan kecepatan putaran generator, Tegangan keluaran generator fluks aksial dipengaruhi oleh beberapa parameter antara lain: kecepatan putaran, jenis magnet, ukuran volume magnet, bentuk dan ukuran kumparan, banyaknya lilitan dalam satu kumparan dan celah udara atau celah udara antara rotor dan stator (21)

Rancangan ukuran rotor dapat disesuaikan dengan ukuran stator, dimana magnet permanen saling berhadapan ditengah - tengah sisi depan dan belakang kumparan. Bahan yang digunakan sebagai tatakan penyangga rotor yaitu besi (Fe), sehingga magnet dapat diletakan pada tatakan penyangga tanpa harus menanam magnet permanen tersebut.

Celah udara (air gap) pada generator axial merupakan jarak antara rotor dan stator. Celah udara (air gap) juga menjadi tempat perpindahan medan magnet melewati kumparan pada stator sehingga menghasilkan nilai fluks magnet yang mempengaruhi tegangan induksi pada kumparan.
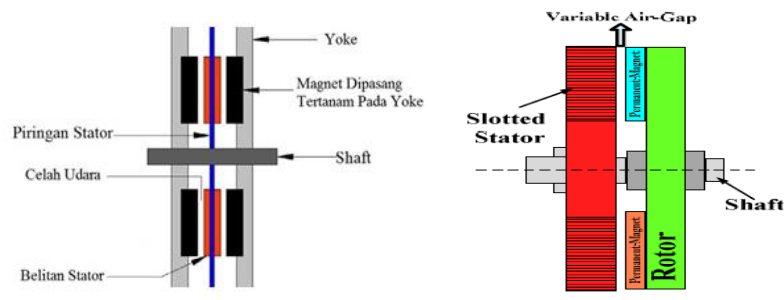

Gambar 1. Variabel air gap
Jenis magnet permanen yang akan digunakan dalam perancangan rotor tersebut adalah jenis magnet permanen neodyniumiron-boron $(\mathrm{NdFeB})$. Magnet permanen jenis ini memiliki nilai medan magnet dan kerapatan fluks magnet yang lebih besar dibandingkan jenis magnet permanen lainnya yaitu sebasar 1,2 tesla. Penggunaan jenis magnet permanen neodyniumironboron $(\mathrm{NdFeB})$ bertujuan untuk memperoleh nilai fluks magnet yang maksimal sehingga memperoleh tegangan induksi yang maksimal. Penentuan ukuran magnet permanen yang digunakan berdasarkan kemampuan peneliti dalam memperoleh magnet permanen tersebut.

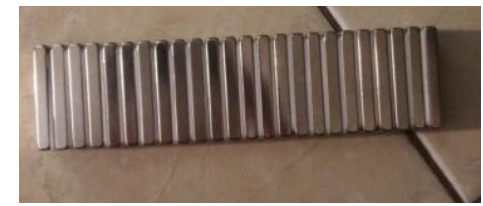

Gambar 2 Magnet permanen neodynium-iron-boron $(\mathrm{NdFeB})$

Rancangan rotor menggunakan 12 pasang kutub disetiap sisi bagian rotor tersebut, perencanaan jumlah kumparan dan magnet permanen yang maksimum akan memperbesar nilai frekuensi dan tegangan induksi yang dihasilkan.

Kombinasi pemasangan antara kutub magnet dilakukan sesuai dengan tipe NS yang bertujuan untuk memperbasar nilai kerapatan fluks magnet diantara kedua rotor

\section{Rotor}

Rotor terdiri dari 2 komponen utama yaitu magnet permanen dan tatakan penyangga magnet permanen (yoke). Rotor pada generator axial tidak memerlukan arus eksitasi dari luar dikarenakan medan magnet yang dihasilkan berasal dari magnet permanen.

Neodynium-iron-boron $(\mathrm{NdFeB})$ menjadi jenis magnet yang paling baik dibandingkan dengan jenis lainnya. Terdapat dua cara penempatan magnet permanen pada tatakan penyangga, yaitu surface mounted dan embedded.
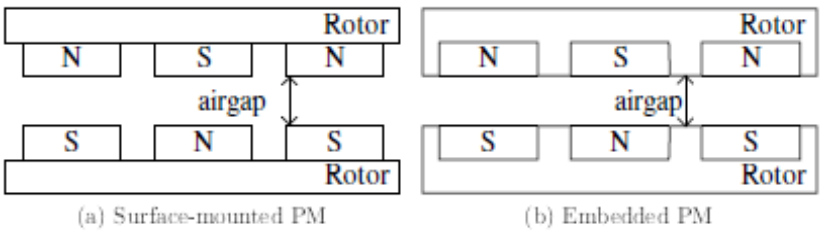

Gambar 3. Prinsip Kerja Generator Sinkron Axial

Hukum Faraday menjadi dasar dari prinsip kerja generator dalam mengkonversi energi mekanik menjadi energi listrik. Penelitian Faraday dan Henry membuktikan bahwa jika sebuah simpul atau kumparan kawat kondukor dilewati oleh fluks magnetik yang berubah terhadap waktu maka pada simpul atau 
kumparan kawat konduktor tersebut akan timbul gaya gerak listrik induksi dan arus induksi. Proses itu sendiri disebut sebagai induksi magnetic

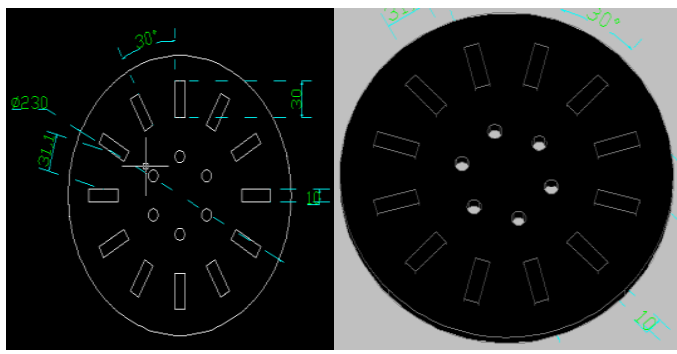

Gambar 4. Skematik rancangan rotor

\section{Fluks Magnetik}

Fluks magnetik berkaitan dengan jumlah garis medan magnet yang melewati luasan yang diketahui. Dalam hal ini, fluks magnet $\left(\Phi_{\mathrm{m}}\right)$ didefinisikan sebagai perkalian medan magnetik B dengan luasan A yang dibatasi oleh rangkaiannya. Jika garis - garis medan magnet melewati suatu luasan yang terdiri atas sebuah kumparan dengan jumlah $\mathrm{N}$ lilitan, maka besar fluks magnet yang dihasilkan yaitu sebesar :

$$
\Phi_{\mathrm{m}}=\text { N.B.A }
$$

Dimana :

$\Phi_{\mathrm{m}} \quad=$ Fluks magnet (weber)

$\mathrm{N} \quad=$ Jumlah lilitan pada kumparan

A $\quad$ = Luas penampang (meter)

Perhitungan fluks magnet yang terdiri dari beberapa kumparan dan magnet permanen yang saling terhubung sebagai berikut :

$$
B_{\max }=B_{r} \cdot \frac{t_{m}}{t_{m}+\delta}
$$

Dimana :

$\mathrm{B}_{\max } \quad=$ Medan magnet maksimal (tesla)

$\mathrm{B}_{\mathrm{r}} \quad=$ Madan magnet relatif (tesla)

$1_{\mathrm{m}} \quad=$ Tinggi magnet (meter)

$\delta \quad=$ Panjang celah udara (meter)

$$
A_{\text {magnet }}=\frac{\pi\left(r 0^{2}-r i^{2}\right)-T^{f}(r o-r i) N_{m}}{N_{m}}
$$

Dimana :

$\mathrm{A}_{\text {magnet }}=$ Luasan medan magnet $(\mathrm{m}$

$\pi \quad=$ Konstanta (3.14)

ro $\quad=$ Radius luar magnet (meter)

ri $\quad=$ Radius dalam magnet (meter)

$\mathrm{f} \quad=$ Jarak antar magnet (meter)

$\mathrm{N}_{\mathrm{m}} \quad=$ Jumlah magnet

$$
\Phi_{\max }=\mathrm{A}_{\text {magnet }} . \mathrm{B}_{\max }
$$

Dimana :

$\Phi_{\max } \quad=$ Nilai fluks maksimal yang akan diinduksikan

$(\mathrm{Wb})$

$\mathrm{A}_{\text {magnet }}=$ Luasan medan magnet $\left(\right.$ meter $\left.^{2}\right)$

$\mathrm{B}_{\max } \quad=$ Medan magnet maksimal (tesla)

Perencanaan Pengukuran Pada Generator Axial

\begin{tabular}{|c|c|c|}
\hline Keterangan & Lambang & $\begin{array}{c}\text { Ukuran- } \\
\text { Satuan }\end{array}$ \\
\hline & Panjang & $30 \mathrm{~mm}$ \\
\hline
\end{tabular}

\begin{tabular}{|l|c|c|}
\hline Dimensi Magnet & $\begin{array}{l}\text { Lebar } \\
\text { Tinggi }\end{array}$ & $\begin{array}{c}10 \mathrm{~mm} \\
4 \mathrm{~mm}\end{array}$ \\
\hline Kerapatan Fluks Magnet & $\mathrm{Br}$ & $1.2 \mathrm{~T}$ \\
\hline Radius Luar Magnet & $\mathrm{Ro}$ & $9.38 \mathrm{~cm}$ \\
\hline Radius Dalam Magnet & $\mathrm{Ri}$ & $6.38 \mathrm{~cm}$ \\
\hline Tabel Magnet & $\mathrm{Lm}$ & $4 \mathrm{~cm}$ \\
\hline Jarak Celah Udara & $\Delta$ & $1,2,3,4,5 \mathrm{~mm}$ \\
\hline Jarak Antar Magnet & $\mathrm{Tf}$ & $2.02 \mathrm{~cm}$ \\
\hline Jumlah Kutub & $\mathrm{Nph}$ & 12 \\
\hline Jumlah Kumparan & $\mathrm{Ns}$ & 12 \\
\hline $\begin{array}{l}\text { Jumlah Lilitan Dalam Satu } \\
\text { Kumparan }\end{array}$ & $\mathrm{N}$ & 200 \\
\hline
\end{tabular}

\section{Perakitan Konstruksi Generator Axial}

Perakitan stator dan rotor dilakukan menggunakan batang besi stenlis berbentuk slinder dengan diameter 17 $\mathrm{mm}$ dan panjang $200 \mathrm{~mm}$ sebagai penghubung diantara keduanya. Pengelasan dilakukan pada rotor dan batang besi sedangkan stator diberi bearing pada tengah stator agar stator tidak ikut berputar pada saat rotor berputar. Untuk kedudukan berdirinya generator dirancang menggunakan besi padat dengan ukuran yang disesuaikan. Kedudukan ini juga bertujuan untuk menahan stator agar tidak ikut berputar pada saat generator dioperasikan.

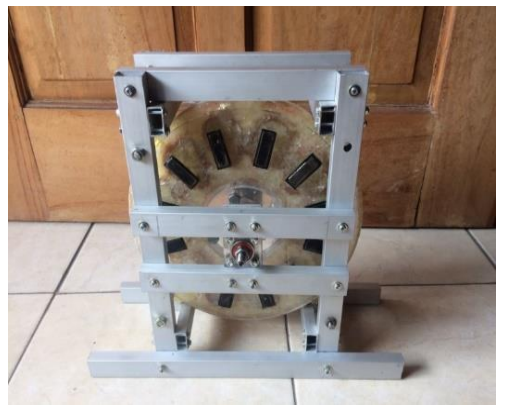

Gambar 4 hasil rancangan generator axial

\section{Analisa Perhitungan dan Pengukuran Frekuensi}

Perhitungan nilai frekuensi dapat dilakukan menggunakan persamaan (5) sesuai dengan penjabaran landasan teori. Adapun salah satu perhitungan nilai frekuensi pada kecepatan rotasi rotor $500 \mathrm{rpm}$ sebagai berikut :

$$
\mathrm{f}=\frac{n P}{120}
$$

Setelah melakukan perhitungan pada setiap skala kecepatan rotasi rotor, dilakukan pengukuran nilai frekuensi menggunakan osiloskop sebanyak 6 kali pengukuran. Hasil dari 6 kali pengukuran tersebut dirata - ratakan sehingga diperoleh nilai frekuensi berdasarkan pengukuran. Hasil Yang diperoleh menggunakan osciloscop dan multimeter dapat dilihat dari tigan tabel di bawah dengan membedakan dari jarak Air Gap yang di pasang.

Tabel 1. Data hasil pengukuran tegangan dan kecepatan untuk Air Gap $2 \mathrm{~mm}$ 


\begin{tabular}{|c|c|c|c|c|}
\hline & Kec. & Tegangan & \multicolumn{2}{|c|}{ Nilai Frekuensi (Hz) } \\
\cline { 4 - 5 } No. & $\begin{array}{c}\text { Rotasi } \\
\text { Rotor } \\
\end{array}$ & (Volt) & $\begin{array}{c}\text { Berdasarkan } \\
\text { Perhitungan }\end{array}$ & $\begin{array}{c}\text { Berdasarkan } \\
\text { Pengukuan }\end{array}$ \\
\hline 1. & 1100 & 70 & 104,5 & 128 \\
\hline 2. & 900 & 50 & 89 & 111 \\
\hline 3. & 600 & 30 & 51,5 & 64,1 \\
\hline 4. & 480 & 25 & 46 & 57,1 \\
\hline 5. & 400 & 22 & 40 & 50 \\
\hline 6. & 250 & 15 & 25 & 35,7 \\
\hline
\end{tabular}

\section{Perhitungan dan Pengukuran Tegangan Induksi}

Perhitungan nilai tegangan efektif dapat dilakukan menggunakan persamaan (7) sesuai dengan penjabaran landasan teori. Adapun salah satu perhitungan nilai tegangan efektif pada kecepatan rotasi $500 \mathrm{rpm}$ sebagai berikut :

$B \max =B_{r} \frac{l m}{l m+\delta}$

\section{$1,2 \frac{0,004}{0,004+0,001}=0,96$ Tesla}

A Magnet $=\frac{\pi\left(r o^{2}-r i^{2}\right)-T f(r o-r i) \cdot N m}{N m}$

$$
\begin{aligned}
& =\frac{3,14\left(0,0938^{2}-0,0638^{2}\right)-0,0202(0,09}{24} \\
& =\frac{3,14(0,00879844-0,00407044)-0,01}{24} \\
& =\frac{0,01484592-0,014544}{24} \\
& =0,00001258 \mathrm{~m}^{2}
\end{aligned}
$$

$\emptyset \max =A$ magnet.$B$ magnet

$$
\begin{aligned}
& =1,258 \times 10^{-5} \cdot 0,96 \\
& =1,208 \times 10^{-5}
\end{aligned}
$$$$
\text { Vrms }=4,44 \cdot N \cdot f \cdot \emptyset \cdot \frac{N s}{N p h}
$$

$$
\begin{gathered}
=4,44.200 \cdot 50 \cdot 1,208 \times 10^{-5} \cdot \frac{12}{1} \\
=6,43 \mathrm{~V}
\end{gathered}
$$

Tabel 2. Data hasil perhitungan Vrms dan Daya untuk variable Air Gap

\begin{tabular}{|c|c|c|c|c|c|}
\hline $\begin{array}{c}\delta \\
(\mathrm{mm} \\
)\end{array}$ & $\begin{array}{c}\mathrm{B} \\
\max \\
\left(\begin{array}{c}\text { tesla } \\
)\end{array}\right.\end{array}$ & $\begin{array}{c}A_{\text {magnet }} \\
\left(\mathrm{m}^{2}\right)\end{array}$ & $\begin{array}{c}\phi_{\text {magnet }} \\
\text { (tesla) }\end{array}$ & $\begin{array}{c}V_{\text {rms }} \\
( \\
\text { volt } \\
)\end{array}$ & $\begin{array}{c}\mathrm{P} \\
(\mathrm{w})\end{array}$ \\
\hline 1 & 0.96 & 0,00001258 & $1,208 \times 10^{-5}$ & 6.43 & $\begin{array}{c}3.7 \\
1\end{array}$ \\
\hline 2 & 0.8 & 0,00001258 & $1,006 \times 10^{-5}$ & 5.36 & $\begin{array}{c}3.0 \\
9\end{array}$ \\
\hline 3 & 0.68 & 0,00001258 & $0.862 \times 10^{-5}$ & 4.58 & $\begin{array}{c}2.6 \\
4\end{array}$ \\
\hline 4 & 0.6 & 0,00001258 & $0.754 \times 10^{-5}$ & 4.01 & $\begin{array}{c}2.3 \\
1\end{array}$ \\
\hline 5 & 0.53 & 0,00001258 & $0.667 \times 10^{-5}$ & 3.55 & $\begin{array}{c}2.0 \\
4\end{array}$ \\
\hline
\end{tabular}

Keterangan tabel di atas dapat menjelaskan bahwa perbedaan frekuensi yang di hasilkan oleh generator axial tersebut berdasarkan perhitungan dan berdasarkan percobaan secara langsung di akibatkan oleh beberapa faktor yang dapat mempengaruhi perbedaan tersebut antara lain :

1. Karena ada faktor toleransi pada alat ukur yang digunakan.

2. Karena kurangnya alat ukur yaitu pengukur kekuatan medan magnet, yang tidak bisa disamakan jika hanya melalui data sheet.

3. Karena faktor tatanan kumparan yang tidak presisi dapat mempengaruhi medan magnet. Hal ini dapat dilihat dari gelombang yang di hasilkan pada osiloskop.

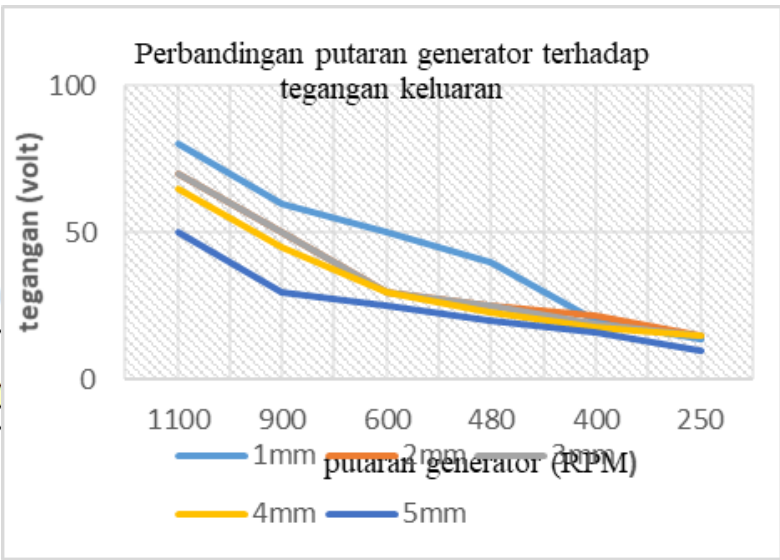

Gambar 5. grafik perbandingan putaran generator terhadap tegangan output

\section{Perbandingan Nilai Frekuensi}

Perbandingan kedua data frekuensidapat dilakukan dengan mengunakan 2 metode perhitungan kesalahan yaitu persentase kesalahan dan standar deviasi. Kedua metode ini bertujuan untuk melihat keakuratan nilai frekuensi yang didapat sehingga pengelolaan data lebih jelas dan dapat dianalisis. Perhitungan kesalahan standar deviasi dilakukan dengan tujuan melihat keakuratan hasil pengukuran nilai frekuensi yang dilakukan sebanyak beberapa kali pada masing - masing skala kecepatan rotasi rotor.

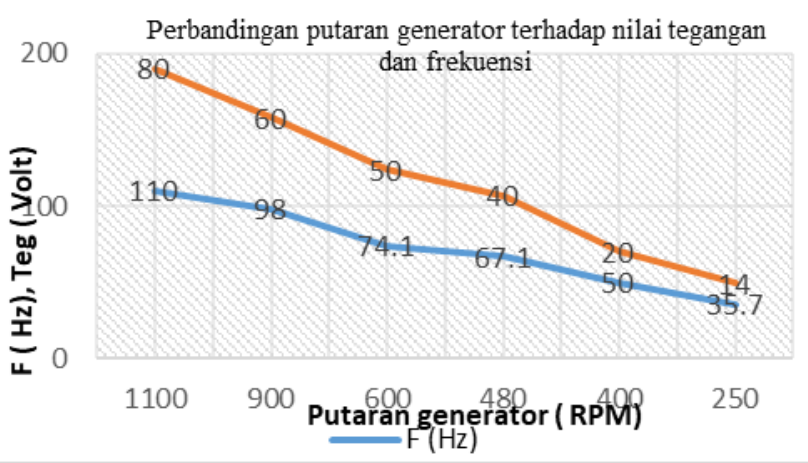

Gambar 6 Perbandingan putaran generator terhadap perubahan nilai frekuensi dan nilai tegangan pada jarak air gap $1 \mathrm{~mm}$ 


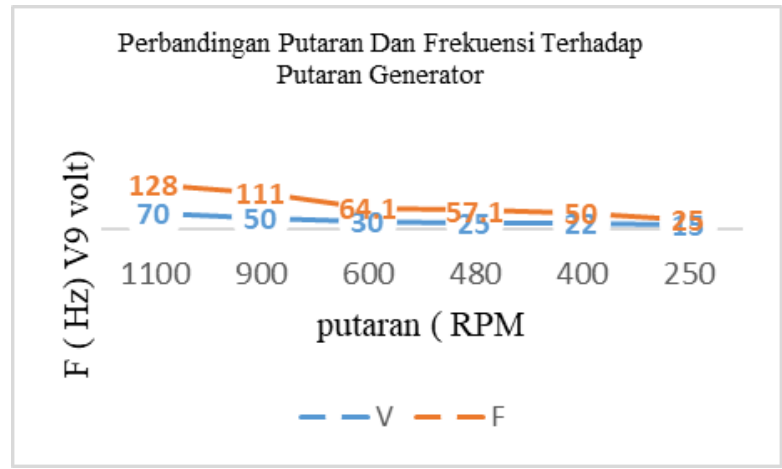

Gambar 7. Perbandingan putaran generator terhadap perubahan nilai frekuensi dan nilai tegangan pada jarak air gap $2 \mathrm{~mm}$

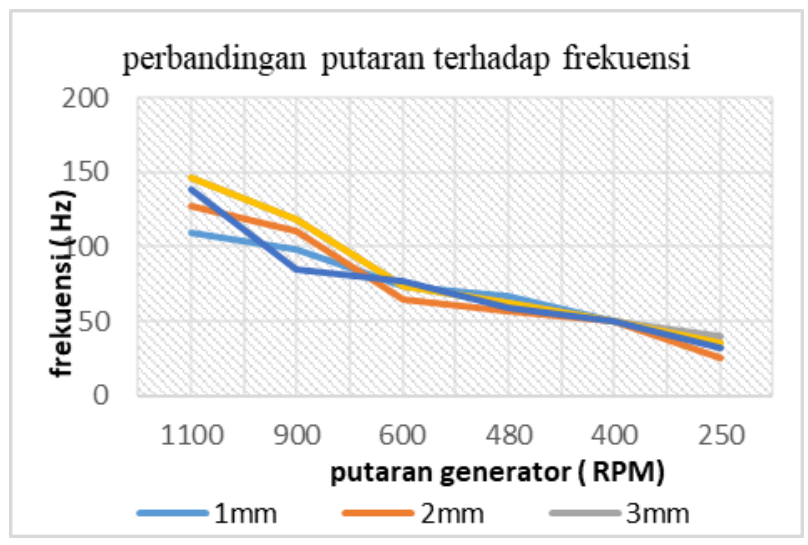

Gambar 7. perbandingan putaran generator terhadap frekuensi

Berdasarkan data pada tabel atas, dapat disimpulkan bahwa satu putaran rotor sama dengan $+/-8$ $\mathrm{Hz}$ frekuensi yang dibangkitkan oleh generator axial. Hal ini sesuai dengan jumlah pasangan kutub magnet permanen pada setiap rotor yaitu sebanyak 12 pasang. Duabelas pasang kutub magnet permanen tersebut menjadi faktor yang mempengaruhi perbedaan nilai kecepatan rotasi pada rotor dengan nilai frekuensi yang dibangkitkan oleh generator. Hal ini sesuai dengan proses terbentuknya satu gelombang penuh sinusoidal pada generator.

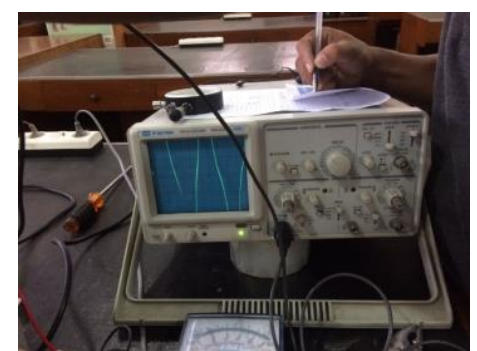

Gambar 8. Bentuk gelombang yang dihasilkan

Gambar diatas merupakan salah satu hasil pengukuran frekuensi pada kecepatan rotasi rotor $100 \mathrm{rpm}$. Jika dilihat dari hasil pengukuran tersebut, bentuk gelombang yang dihasilkan mendekati gelombang sinusoidal (tidak sempurna).

\section{SIMPULAN}

Pada perancangan generator listrik fluks aksial berbasis magnet permanen ndfeb telah berhasil dibuat. dengan variasi air gap, pada pengujian tegangan output generator fluks aksial adalah berbanding terbalik secara linier. besarnya remanansi (br) magnet permanen ndfeb yang digunakan pada rotor generator listrik fluks aksial berbanding lurus terhadap output tegangan (erms). peningkatan air gap berkorelasi secara eksponensial terhadap fluks magnetik, jarak air gap terbaik generator ini adalah $2 \mathrm{~mm}$ dimana generator menghasilkan tegangan 22 volt ac pada putaran $400 \mathrm{rpm}$ dengan frekuensi $50 \mathrm{hz}$.

\section{DAFTAR PUSTAKA}

[1] Achmad Maulana Soehada S, Candra Kurniawan, Perdamean Sebayang, 2017, Efek Air Gap Pada Rancang Bangun Dan Uji Performa Generator Listrik Fluks Aksial Berbasis Magnet Permanen Ndfeb, Journal Of Technical Engineering: Piston, Vol. 1, No. 1, Hal. 6-12, 2017

[2] Arnold David P, Florian Herrault, Iulica Zana, Preston Galle, Jin-Woo Park, Sauparna Das, Jeffrey $\mathrm{H}$ Lang and Mark G Allen, 2006, "Design optimization of an $8 \mathrm{~W}$, microscale axial-flux, permanent-magnet generator". Journal of Micromechanics and Microengineering S290S296. 2006.

[3]. A. Parviainen, "Design of Axial Flux Permanent Magnet Low Speed Machines and Performance Comparison between Radial-Flux and Axial-Flux Machines," Thesis for the degree of Doctor of Science (Technology), University of Technology, Lappeenranta, Finland, hal. 1-153, 2005.

[4]. A. Parviainen,M. Niemela,J. Pyrhonen,J. Mantere, "Performancecomparison between low-speed axialflux and radial-flux permanent magnetmachines including mechanical constraints,"IEEE International Conference on Electric Machines and Drives, hal. 1695-1702, 2005.

[5] Ahmed D. Dan A. Ahmad, "An optimal design of coreless direct-drive axial fluxpermanent magnet generator for wind turbine,"Journal of Physics: Conference Series, 439, 012039, 2013.

[6]. Akatsu K. Dan Wakui S., "A comparison between axial and radial flux PMmotor by optimum design method from the required output NT characteristics,"COMPEL: The International Journal for Computation and Mathematics in Electrical and Electronic Engineering, vol. 25, hal. 496-509, 2006.

[7]. Davila-Vilchis J.M. dan R.S. Mishr, "Performance of a hydrokinetic energy system using an axialflux permanent magnet generator,"Energy, vol.65, hal. 631-638, 2014 
[8] D. Lahouel, D. Hedjazi, R. Abdessemed, 2019, Sizing inductors of an axial flux synchronous generator, International Journal of Applied Power Engineering (IJAPE), Vol.8, No.2, August 2019, pp. 110 119

[9] Franjo PRANJIĆ, Peter VIRTIČ, 2018, Determination of an Optimum Fictitious Air Gap and Rotor Disk Thickness for a Coreless AFPM, jurnal Tehnički vjesnik 25, 6(2018), 1731-1738

[10] Gieras, Jacek F., Rong Jie-Wang, Maarten J Kamper.. Axial Flux Permanent Magnet Brushless Machine. Second edition. Springer.New York, 2008

[11] G. F. Price, T. D. Batzel, M. Comanescu, dan B. A. Muller,"Design and Testing of a Permanet Magnet Axial Flux Wind Power Generator,"Proc.The $2008 \quad$ IAJC-IJME International Conference, 2008.

[12] Gargov N.P., A.F. Zobaa, dan I. Pisica,2014, "Separated magnet yoke for permanent magnet linear generator for marine wave energy converters,"Electric Power Systems Research,vol. 109, hal. 63-70, 2014

[13] Hari Prasetijo Sugeng Waluyo,2015, Optimasi Lebar Celah Udara Generator Axial Magnet Permanen Putaran Rendah 1 Fase, JNTETI, Vol. 4, No. 4, November 2015)

[14] Herudin, Wahyu Dwi Prasetyo, 2016, Rancang Bangun Generator Sinkron 1 Fasa Magnet Permanen Kecepatan Rendah 750 Rpm, Jurnal Ilmiah Setrum - Volume 5, No.1, Juni 2016

[15] K.C. Latoufis, G.M. Messini, P.C. Kotsampopoulos And N.D, 2012, Axial Flux Permanent Magnet Generator Design For Low Cost Manufacturing Of Small Wind Turbines, Wind Engineering Volume 36, No. 4, 2012

[16]. Muljadi, P. Sardjono, Suprapedi, "Preparation and characterization of 5 wt. persen epoxy resin bonded magnet $\mathrm{NdFeB}$ for micro generator application,"Energy Procedia, vol. 68, hal.282-287, 2015.

[17] M.Pinilla, S. Martinez,2012, "Optimal design of permanent-magnet direct drive generator for wind energy considering the cost uncertainty in raw materials,"Renewable Energy,vol. 41, hal. 267276,2012 .

[18] Nurtjahjomulyo,A.. "Rancang Bangun Generator Turbin Angin Tipe Aksial Kapasitas 200 w Jurnal Teknologi Dirgantara. 2010.

[19] Pudji Irasari, Novrita Idayanti, "Aplikasi Magnet Permanen Bal2fe19o Dan Ndfeb Padaa Generator Magnet Permanen Putaran Rendah". Jurnal Sains Material Indonesia,Vol 11 No 1 Hal: 38-41.Lipi, 2007.

[20] Sedat Nazlibilek, Esmail S. Eb. Mohammed, 2017, Air Gap Effect on the AFPM Generator (Inner Rotor) Performance, International Journal of
Engineering Research and Development, Volume 13, Issue 1 (January 2017), PP.37-43

[21] Syafriyudin, M.Suyanto,Irawadi Buyung, 2019, Design of Low Speed Generator 1 Phase Using Permanent Magnetic Type Neodymium, Volume 807(011001)Journal of Physics, Conference Series: Materials Science and Engineering, 